\title{
Embryo-sac Development in Two Accessions of Giant Pangola Digitaria valida Stent
}

\author{
Caridad María Purcell
}

\section{INTRODUC:TION}

Common Pangola, Digilaria decumbens Stent, is an excellent forage plant, being one of the most important species in Puerto Rico, but it is highly sterile. It has been found that it is male sterile as well as female because of meiotic irregularities (2)². Giant Pangola, Digitaria valida Stent, Kob grass, or Kob Hill Grass $(4,5)$ grows taller and with broader leaves than the rommon Pangola. Because it posscsses some desirable forage characteristics it appeared to have usefulness in a breeding program, provided it was sexually reproduced. Before selecting it as jarent al material for breeding, its reproductive behavior had to be studied. Preliminary observations of very low seed set and meiotic irregularities raised questions about its potential value for breeding (3). Eleven South African Digitaria ralida accessions have been kept under observation at the Agricultural Experiment Station in recent years. Two of them show a high percent age of pollen stainability, 77 to 94 percent, resjectively, a regular meiosis in P.IC, and have produced a progeny that revealed genetic recombination $(G)$. The present investigation was conducted to obtain information about the cmbryo-sac: development in these 1 wo areessions and its probable relation with the low seed set.

\section{MA'TEIRALS ANI) METHODS}

The accessions in (uestion bear the labels 1950C and 1953A, corresponding to USDA plant introduction Nos. 209177 and 209372, respectively. Both are from Transvaal, 1950C originating from Krüger Xational Park, 19533A from an unmamed locality between Zeerust and Ottohoop).

Whole sipikes were killed and fixed in CRAF solution. Ovaries were dissected and dehydrated with the n-butyl alcohol series, and embedded in paraffin. Sections were cut at 10 to $12 \mu$, and stained with propionic-('armine. By sectioning progressively older ovules, it was possible to follow the developmental secpuence.

Photomicrographs were laken with a Jecitz Makam camela mounted on a Leit \% Ortholux research microscope. Final magnification is $820 \times$.

'Research Assistant in Plant Breeding. Agricultural Experiment Station, Iniversity of Puerto Rico, Rio Piedras, P.R. The anthor wishes to express her sincere gratitude to Dr. Niilo Virkki, under whose direetion this study was conducted.

2 Italie numbers in parentheses refer to litenture Cited, pp. 482-3. 


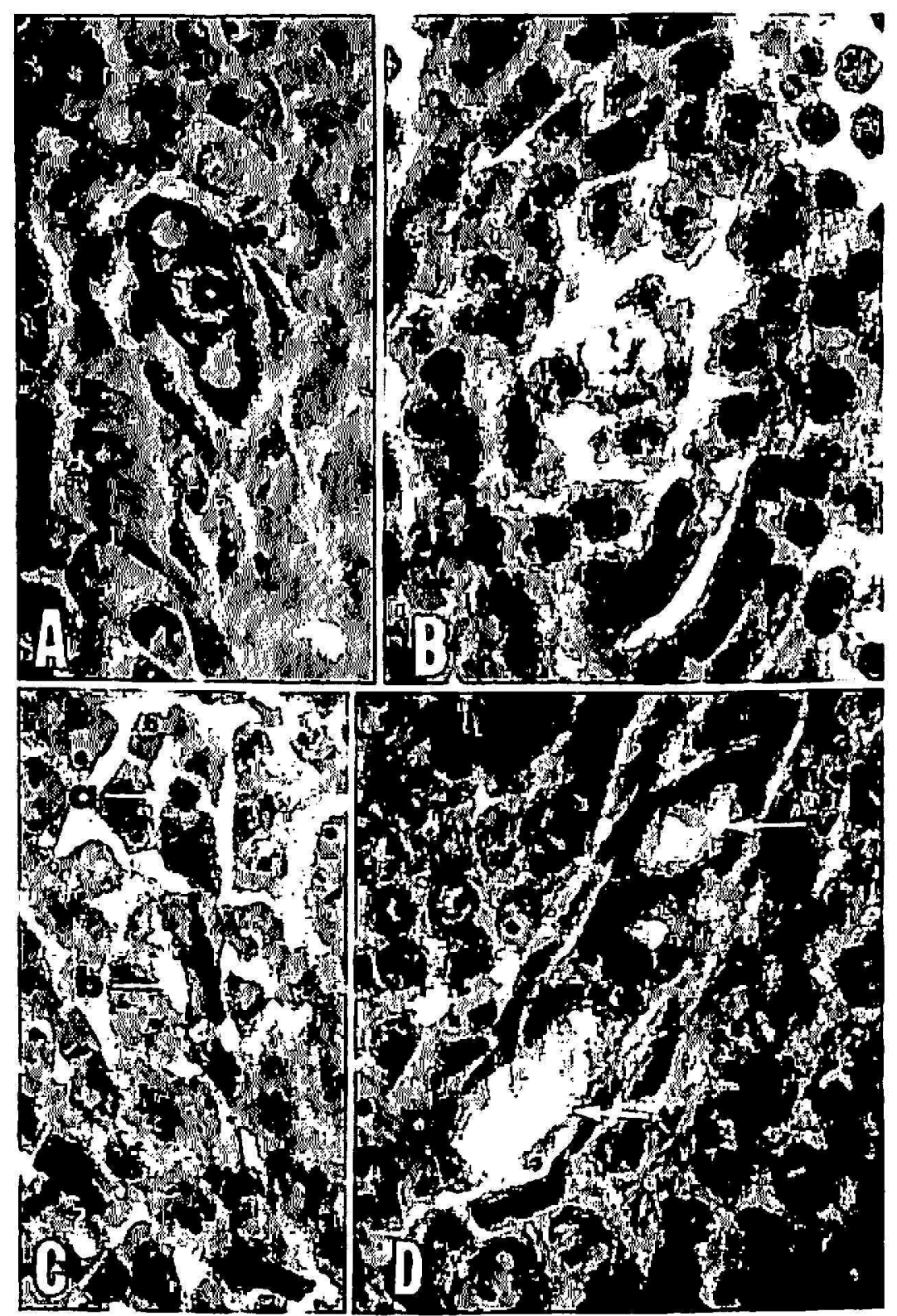

Fra. 1.- A, Archesporial cell differentiated from a single nucellar cell; B, pachytene stage in the MMC first meintic division; $C$, an, functional cell and $b$, the 3 megaspores nearest the micropyle disintegrating; I), the enlarged megaspore with 1 vacuole (v) on either side of the nucleus.

\section{OHSLRVATIONS}

\section{TORMAL EMBRYO-SAC}

The ovary of Digitaria ralida has a single anatropous ovule, and the cmbryo-sac is of the Polygonium type (1).

The arresporial cell differentiates from a single hypodermal rell of the nucellus, (fig. 1,A) and undergoes two meiotic divisions forming a linear tetrad of megaspores. The meiosis is supposedly normal, but the artual division stages were not observed except for the parhytene stage in the 
MIIC first meiotic division, (fig. 1,B). After the meiosis the three megaspores nearest the micropyle disintegrate, leaving the chalazal member as the functional cell (fig. 1,C).

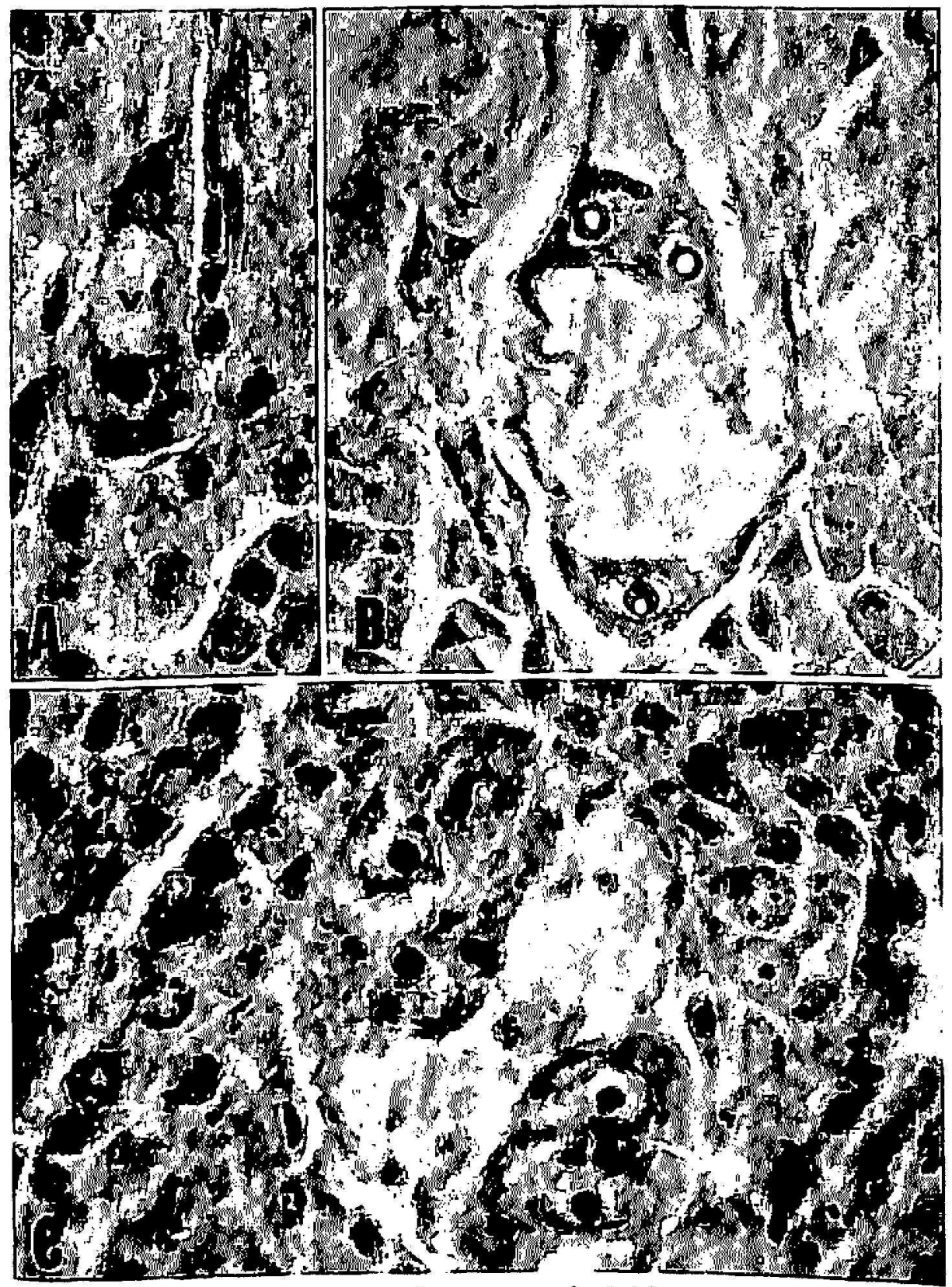

FIG. 2,-A, The 2-nucleate stagc, a large vacuole (v) bet ween the 2 daughter nuclei; $\mathrm{B}$, the 4-nucleate stage; $\mathrm{C}$, the 8 -nucleate stage.

The megaspore nucleus enlarges and its enlargement is accompanied by increased vacuolation of the rytoplasm, one varuole appearing on either side of the nucleus (1) (fig. 1,D). After the first division has taken plare, the two daughter nuclei migrate to opposite poles leaving between them a large vacuole (fig. $2, \mathrm{~A}$ ). The next division gives rise 10 a t-nucleate st age (fig. 2,B) and the following division to the 8-nucleate stage (fig. 2,C). 

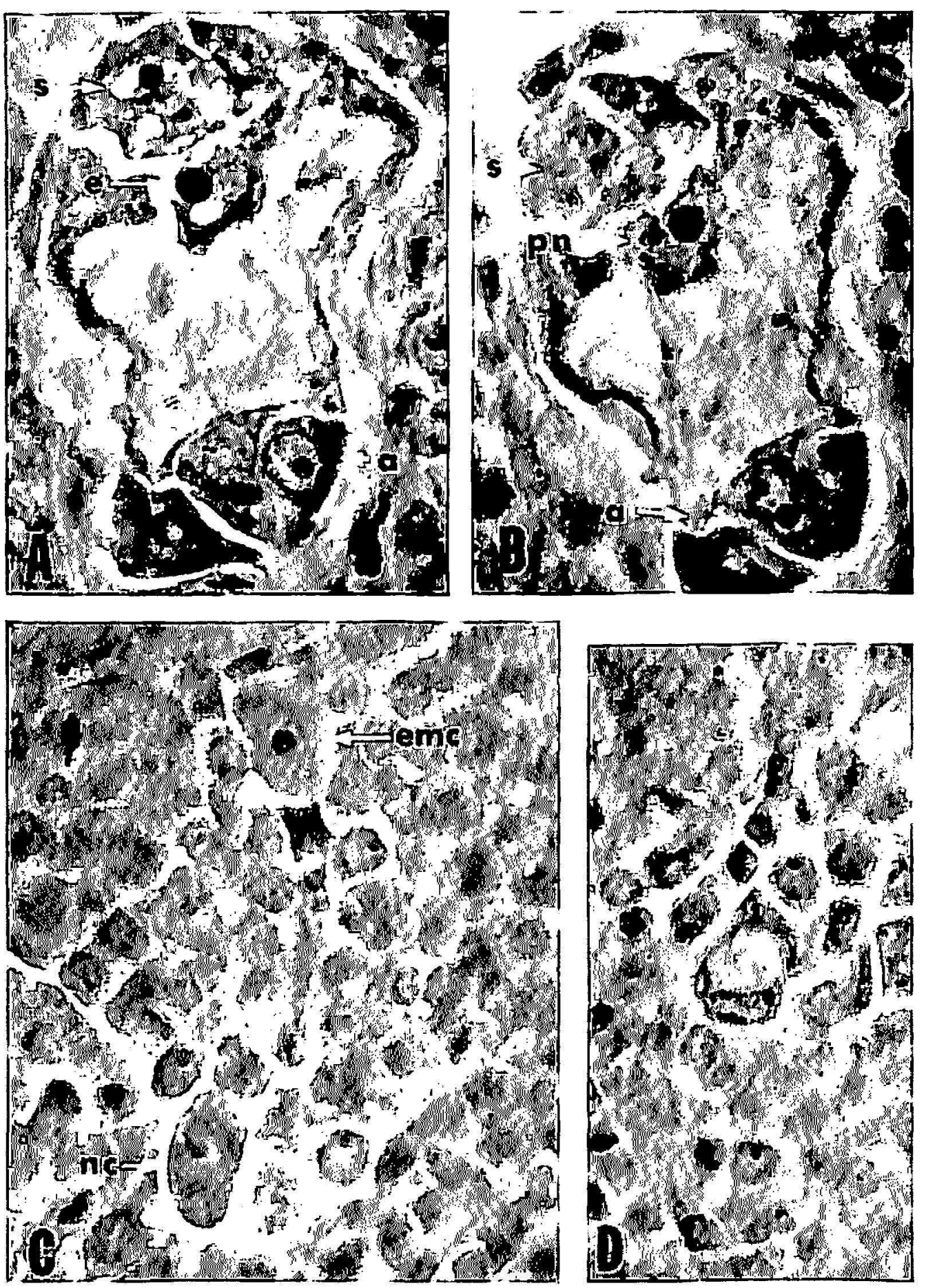

FI(i. 3.- A, B, The complete embryo-sac. A, s, synergids; e, egg; a, antipodals. B, s. synergids; pn, polar nuclei; a, antipodals. C, Nucellar cell (ne) growing along with the functional megaspore (enc). 1), A t-mucleate apomictic embryo-sac.

The normal embryo-sac is always composed of more than eight muclei. This condition arises by the oreurrence of secondary divisions of the antipodals since sales with up 10 seven and eight antipodals were encountered.

The mature combryo-siac ('onsists of an egg applatatus, two polar nuclei, and the ant ipodals, ranging in number from + to 8 , (fig. $3, A, B$ ). The egg 
apparatus consists of two synergids and the egg. The antipodals are usually present until the development of the embryo is well under way.

\section{APOMICTIC SAC}

There is a very strong tendency to apomixis. The apomictic nucellar cells are encountered in about 50 to 60 percent of the ovules. They can be seen

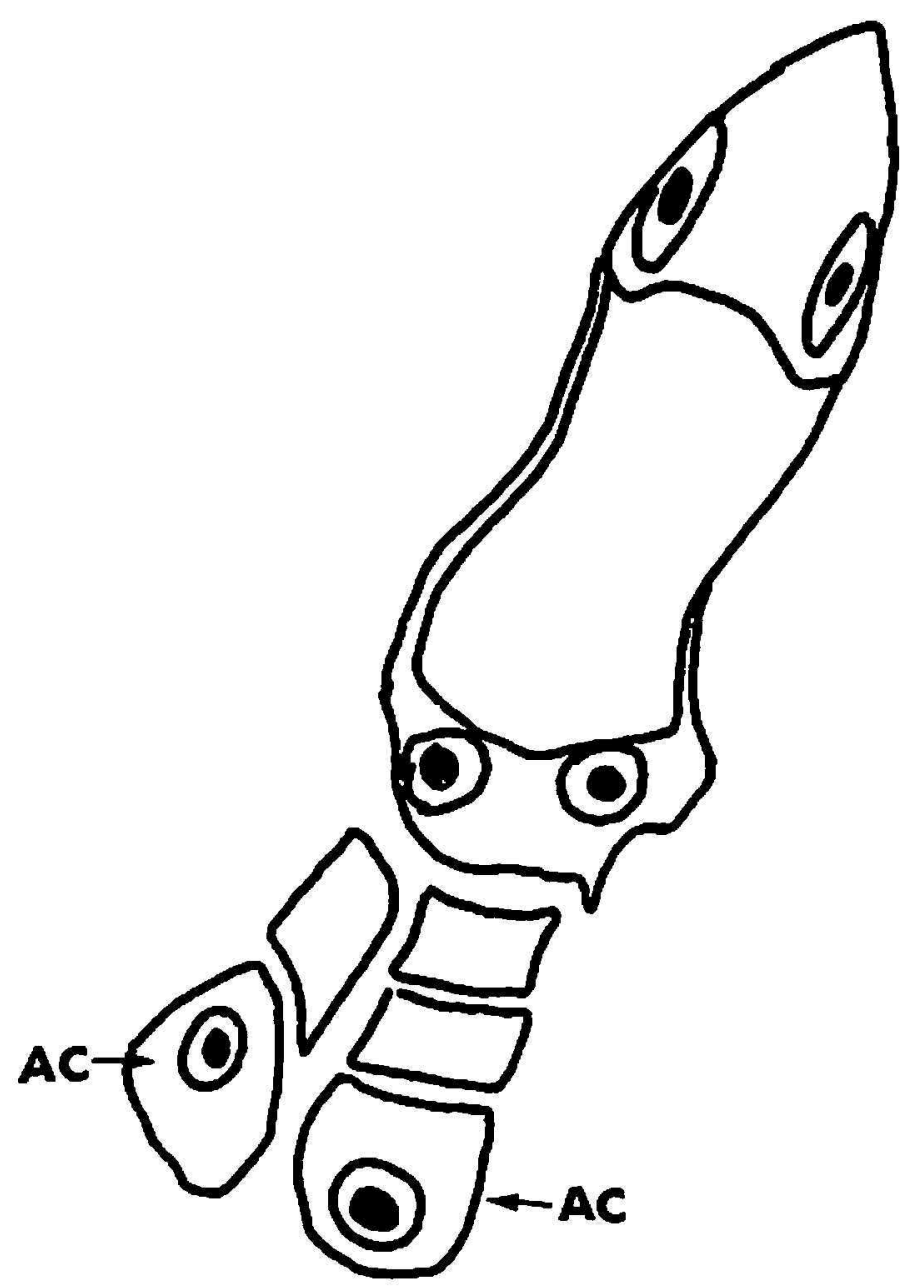

FIG. 4.-Apomictic nucellar cells (AC) growing along with the maturing normal embryo-sac.

growing along with the functional megaspore (fig. 3,C) or enlarging while the normal embryo-sac is almost mature. These apomictic nucellar cells, when present, are usually located near the antipodal region of the sac, (fig. 4). However, they may be found at the micropylar region, too. From all the material studied only one case of a small apomictic embryo-sac was encountered, (fig. 3,D). However, whenever apomictic nucellar cells were present the normal embryo-sac development did not proceed at normal pace. In many cases there was a complete arrest of the developing em- 
bryo-sac; in other cases a mature normal sac might be encountered with one or more apomictic nucellar cells.

\section{DISCUSSION}

As long as an ovule is free from apomictic cells the development of the embryo-sac is normal. It is probable that the low seed set is due to apomictic cells which prevent the development of the normal sac, though there is no significant evidence of the formation of apomictic embryo-sac either. Apparently one inhibits the other. The percentage of ovules that presented apomictic nucellar cells included the second flower from every spikelet. According to Sheth et al. (2) the Pangola grass spikelets contain a lower sterile and an upper perfect floret. If this condition holds true for Digitaria valida as it does for Digitaria decumbens, then the future looks hopeful for a breeding program using it. Apparently it does hold true because a marked morphological difference is apparent and can be noticed by just looking at the flower. The lower floret is usually smaller in size and looks as if it were empty.

Contrary to what Sotomayor Ríos, et al. (3) found in other Digitaria valida accession, no significant evidence of meiotic irregularities in the PMC was encountered in these accessions, $1950 \mathrm{C}$ and 1953A, and the number of chromosomes was lower than that informed by them, $2 n=38$ and $2 n=36$, respectively. Apparently the difficulty for seed production is the presence of the apomictic nucellar cells aside from other inherent characteristics.

\section{SUMMARY}

The embryo-sac development of two accessions of Digitaria valida Stent has been studied in an effort to clarify their reproductive behavior.

Even though irregular competition of nucellar cells was observed, a relatively high degree of normality was found in the development of the embryosac. It is concluded that these two accessions of Giant Pangola may be used for a breeding program and promising results may be expected.

\section{RESUMEN}

Se estudió el saco embrionario de dos espécimenes introducidos de Digitaria valida Stent. (Pangola Gigante) para entender mejor el proceso de su desarrollo.

Aun cuando se observó cierta competencia irregular entre las células nucelares, se evidenció una relativa normalidad en el desarrollo del saco embrionario. Por tanto, si se usan estos dos espécimenes de Pangola Gigante en un programa de cruzamientos, los resultados podrían ser prometedores.

\section{LITERATURE CITED}

1. Maheshwari, P., An Introduction to the Embryology of Angiosperms, 1st ed., McGraw-Hill, NewYork-Toronto-London, 1950. 
2. Sheth, A. A., Yu, L., and Edwardson, J., Sterility in Pangola grass (Digitaria decumbens Stent), Agron. J., 48: 505-7, 1956.

3. Sotomayor-Ríos, A., Schertz, F., Woodbury, R., and Velez-Fortuño, J., Taxonomic description and reproductive behavior of giant pangola (Digitaria valida Stent), J. Agr. Univ. P.R., 44 (2): 53-9, 1960.

4. University of Florida, Annual Rpt., Agr. Expt. Sta., p. 127, 1951.

5. University of Florida, Annual Rpt., Agr. Expt. Sta., p. 250, 1954.

6. Virkki, N., Purcell, C. M., (in preparation). 